\title{
An Empirical Study of Success Factors in Transforming Accounting and Engineering Professionals into Entrepreneurs in the SME Sector, Sri Lanka
}

\author{
Randi Kailashinie Thiranagama
}

\begin{abstract}
This paper examines the success factors in transforming Accounting and Engineering Professionals into entrepreneurs in the Small and Medium Enterprise (SME) sector in Sri Lanka. Employing a qualitative research approach methodology, twelve semi-structured interviews and three focus group discussions were conducted with entrepreneurs who have successfully become entrepreneurs in the SME sector. The findings of the study clearly indicate that personal success factors such as risk taking, need for achievement, internal locus of control, professional confidence, passion, need for recognition, need to serve society and opportunity seeking help Engineers and Accountants to emerge as entrepreneurs. It is further influenced by environmental success factors such as family background, perceived government policies, social networks and entrepreneurial culture. Moreover, it reveals that entrepreneurial engineers tend to start ventures in the field of technology whereas entrepreneurial accountants belong to various types of disciplines. The paper concludes with a discussion on the practical implications of the findings for Engineers, Accountants and national policy makers.
\end{abstract}

Keywords: accountants, engineers, entrepreneurship, environmental factors, personal factors, small and medium enterprises.

\section{Introduction}

This study examines the success factors which lead engineers and accountants to start their own businesses as SME entrepreneurs in Sri Lanka. Entrepreneurial ventures have been found to be instruments of change and economic growth (Aloulou \& Fayolle 2005). The

Randi Kailashinie Thiranagama is Senior Manager-Finance at the National School of Business Management. E-mail: kailashinie@nsbm.lk 
An Empirical Study of Success Factors in Transforming Accounting and Engineering Professionals into Entrepreneurs in the Small and Medium Enterprise Sector, Sri Lanka

industry sector, of which approximately $90 \%$ consists of SMEs in Sri Lanka, represents about $26 \%$ of GDP of the country. Therefore the SME sector in Sri Lanka has been identified as an important strategic sector for promoting economic growth and social development of the country (Wickramasinghe 2011).

It is vital to have educated entrepreneurs for SME development in Sri Lanka. According to Romer (1994), the role of entrepreneurship has been highlighted by the new growth theory with an emphasis on "knowledge" as a major factor influencing economic growth. Acs and Varga (2005) identify the relationship between variations in entrepreneurial activity of countries and the spatial structure of economies with the dissemination of knowledge, and economic growth. Therefore, it confirms the importance of graduate entrepreneurs for national development (Muhammad et al. 2011).

Gamage (2010) identified that educated entrepreneurs are important for the development of SMEs because technical and managerial skills are important factors in SME development. In addition, owing to the absence of different skills such as marketing and business development, most SMEs remain at the same level and do not grow into large scale businesses.

The presence of more professional entrepreneurs is significant for the development of the SME sector in a country. However, in the Sri Lankan context, the majority of professional engineers and accountants prefer working for an employer rather than starting their own businesses (Mallawa 2000). Motivating these professionals to move towards entrepreneurship is a challenging feat in any economy (Alwis et al. 2010). The perceived risk and the opportunity cost associated with full-time entrepreneurship can be a sufficient deterrent for a professional to forego the safety of being a wage earner (Alwis et al. 2010).

The outflow of migrating professionals has been continuing since 1960 mainly to work and live in the UK, USA, Canada and Australia (Liyanagama \& Wijewardana 2011). Regardless of the demand for jobs especially in engineering and accounting, 115 engineers and 143 Accountants have left the country adding to the shortage of knowledge workers in the country in 2007 (Liyanagama \& Wijewardana 2011). Also in the Sri Lankan context, it has been shown that this trend among engineers who have received patents for their inventions is much lower than in other non-engineering sectors (Mallawa 2000). Similarly, there is hardly any data available about entrepreneurs with an accounting background who have started their own business and not enough empirically validated data about entrepreneurial accountants. It is important to note that the emergence of entrepreneurial accountants is not impossible because the functions of an accountant may not be routine, unchallenging or risk-free. There is much room for creativity, initiative and risk-taking (Gunawardene 2011). 
NSBM Journal of Management

Vol. 1, No. 1, January - June, 2015

This paper makes use of the experience of Sri Lankan entrepreneurs from engineering and accounting backgrounds to understand their internal and external motivations to become entrepreneurs. It also highlights the impeding factors that prevent them from becoming entrepreneurs.

\section{Literature Review}

\section{SMEs and Entrepreneurship}

Entrepreneurship plays an important role in the economy of a country by extending innovation, nourishing competitiveness, creating jobs and further enhancing economic richness (Guasch, Kuznetsov \& Sanchez 2002, Holmgren \& From 2005). This concurs with Schumpeter (1934), who emphasized the role of the entrepreneur as a prime causative agent of economic development. The emergence and development of entrepreneurship is an important phenomenon in contemporary economies. Entrepreneurship is strongly linked to SMEs, which are the main driving force in developed market economies. In many developed countries, the ratio of SMEs to the total number of enterprises is higher than $95 \%$, while $60 \%$ of the available workforce is employed in those firms (Schmiemann 2008). However, in Sri Lanka, there is not even a clear definition of SMEs. Different government agencies use different criteria to identify SMEs. However, using the size of capital and the number of employees as the criteria, the Industrial Development Board (IDB) defines a small industry as an establishment whose capital investment in plant and machinery does not exceed Rs. 4 million (US\$ 42,000) and the total number of regular employees does not exceed 50 persons (Central Bank of Sri Lanka 1998). The Department of Small Industries (DSI) classifies enterprises with a capital investment of less than Rs. 5 million (US\$ 52,500) and fewer than 50 employees as SMEs (Ponnamperuma 2000).

\section{Personal Success Factors}

Personal factors have been studied by entrepreneurship researchers as the reasons for new venture creation. A number of psychological attributes have been suggested as predictors of entrepreneurial behaviour in the entrepreneurship literature, with some degree of consensus. According to Gorman et al. (1997), the propensity for, entrepreneurship is associated with several personal characteristics: values and attitudes, personal goals, creativity, risk-taking propensity, and locus of control. Of the personal characteristics, McClelland (1961) proposed motivation to achieve, taking risks and locus of control as important characteristics. 
An Empirical Study of Success Factors in Transforming Accounting and Engineering Professionals into Entrepreneurs in the Small and Medium Enterprise Sector, Sri Lanka

McClelland (1961,p.210) emphasized that "practically all theorists agree that entrepreneurship involves, by definition, taking risks of some kind". Risk taking appears to be one of the most distinctive features of entrepreneurial behavior, since creating new ventures is by definition a risky business. Successful entrepreneurs would be willing to bear risk. But they must not only have the motivation to bear risk but must be able to bear the same risk (Say 1971).

In McClelland's (1961) The Achieving Society, the need for achievement (n-Ach) trait has been empirically linked to entrepreneurial activity. The need for achievement is defined as a tendency to choose and persist in activities that hold a moderate chance of success or maximum opportunity for personal achievement satisfaction without undue risk of failure. McClelland conducted a number of studies demonstrating that high n-Ach and the subsequent manifestation of the above behaviours correlated strongly with entrepreneurial success.

Rotter (1966) defined locus of control as an individual's perception of the underlying main causes of events in his/her life. Or, more simply, the individual believes that his/her behaviour is guided by his/her personal decisions and efforts (internal); or is unrelated to his or her actions and is guided by fate, luck, or other external circumstances (external). People with internal locus of control believe that they can control what happens in their lives. On the other hand, people with external locus of control tend to believe that most of the events in their lives result from luck, being at the right place at the right time, and the behaviours of powerful people.

\section{Environmental Success Factors}

Entrepreneurship researchers have found that environmental factors such as satisfactory government support, access to capital and support of family and friends contribute to the success of SMEs (Benzing et al. 2009).

The 'family embeddedness' perspective describes the impact and the importance of family for the entrepreneurial career of their offspring (Aldrich \& Cliff 2003). Experiences during early childhood and socialization at home and in school probably shape the attitudes of people towards entrepreneurship (Basu \& Virick 2008). Parents act as initial role models and parents who are active in a family business influence the future entrepreneurial intentions of their offspring by changing attitudes and beliefs, for example, self-efficacy (Shapero \& Sokol 1982). 


\section{NSBM Journal of Management}

Vol. 1, No. 1, January - June, 2015

Many governments in the world (Chaston 1992, Mulhern 1996)have been paying much attention to SME development in order to strengthen the national economy. In short, government support is a necessary condition for fostering SME development. Government regulations were identified by Reynolds and Lancaster (2006) to be among the top problems faced by UK SMEs. In addition to lack of financial support as mentioned above, lack of institutional support was an obstacle to SME development (Mead \& Liedholm 1998, Swierczek \& Ha 2003).

Most people have contacts; regular, frequent or sporadic, with a great many other people (Pool \& Kochen 1978), and an individual's personal social network consists of all of the people that the individual knows both well and not so well (Barnes 1972). Entrepreneurs' personal social networks have been called the 'most significant resource of the firm' (Johannisson 1990, p. 41), and social encounters between an entrepreneur and his/her network contacts are often a source of new venture ideas (Christensen \& Peterson 1990). To establish a firm, potential entrepreneurs look for relations on the basis of common interests or experience in establishing and running a business (Nohria 1992). Entrepreneurs are also linked to people and organizations that interact among themselves and these contacts can widen the availability of resources that sustain a new firm (Hansen 1995). These relations may extend across professional networks, reaching friends, and colleagues from earlier jobs.

The literature review shows evidence that personal factors such as risk taking, need for achievement, locus of control and environmental factors such as family background, social networks and perceived government policies impact a person becoming an entrepreneur. The researchers used those six factors as a framework to empirically validate whether the same factors or different factors influence engineers and accountants to become entrepreneurs in the SME sector.

\section{Propositions}

The following propositions are identified in relation to investigation:

P1: Personal success factors of risk taking, need for achievement and locus of control influence engineers and accountants to become entrepreneurs in the SME sector.

P2: Environmental success factors of family background, social networks, and perceived government policies influence engineers and accountants to become entrepreneurs in the SME sector. 
An Empirical Study of Success Factors in Transforming Accounting and Engineering Professionals into Entrepreneurs in the Small and Medium Enterprise Sector, Sri Lanka

\section{Methodology}

This study was based on the social constructionist philosophical premise, and employed the grounded theory strategy of inquiry (Strauss \& Corbin 1990). As this was an explorative study, the qualitative method was used. Leedy and Ormorod (2011) recommended the qualitative method for research that interprets certain phenomena. Therefore, a qualitative research technique using one-on-one in-depth interviews was considered to be the most suitable process to identify the success factors affecting engineers and accountants to become entrepreneurs.

The target population consisted of engineers and accountants, male and female, of varying ages, who have successfully made the transformation from an engineering and accounting career to entrepreneurial engineer and accountant. The criteria for selecting informants were: being an individual with a professional qualification or a degree in the fields of Engineering and Accounting and being the founder of the venture with active involvement in the venture. A summary of the informants together with the profession and the business areas is given in Table 1.

Table 1: Details of Informants

\begin{tabular}{llll}
\hline Informant Reference & Profession & Area of the Business & \\
\hline GEML & Telecom Engineer & Telco Solutions & \\
EBHL & Mechanical Engineer & $\begin{array}{l}\text { Automation and Customization of } \\
\text { Electrical Solutions }\end{array}$ & Electronic/ \\
EDBL & Telecom Engineer & Software Solutions & \\
ETTM & Software Engineer & Customized Trading and Consultancy & \\
ACCD & Accountant & Auditing \& Consultancy \\
ATMD & Accountant & Manufacturing & \\
APTC & Accountant & Bakery & \\
ESEV & Software Engineer & Software Solutions \\
ARAL & Accountant & Education & \\
AUMH & Accountant & Heating & \\
EDKR & Software Engineer & Online Delivery Services \\
EWBT & Software Engineer & Transport & \\
\hline
\end{tabular}

Source: Primary Data

Convenience and snowball sampling were used. As the population was unknown, nonprobability sampling was considered the most appropriate sampling technique. The interview guide was derived from the literature review and pilot study. Data analysis in qualitative 


\section{NSBM Journal of Management}

Vol. 1, No. 1, January - June, 2015

research can be compared to "the peeling off the layers of an onion". It is where the researcher peels off the layers of data, applies his analytic powers and emerges with the findings (Merriam 1998). The analysis method used in this research project was a combination of narrative analysis, constant comparative analysis, and content analysis.

Qualitative research needs to convince the reader that the study makes sense, unlike quantitative research that has to convince the reader that procedures have been followed faithfully (Merriam 1998). In order to introduce rigour into this research, the analyzed data was presented to the interviewees and thereafter confirmation was obtained of the accuracy. Further, focus groups were used to validate the preliminary findings and they were discussed with experts, in order to determine whether the results are reasonable. This will reduce the researchers' bias, which as Daft (1983) points out, is inevitable. Instead of trying to achieve an objective position, it is preferable to accept the subjectivity of the interview process and to introduce rigour by using another researcher's opinion (Gillham 2005). Therefore, the researcher discussed the analysis and findings of the study to achieve objectivity.

\section{Results and Discussion}

\section{Influence of Personal Factors in the Transformation of Employed Engineers and Accountants into Entrepreneurial Engineers and Accountants}

Risk taking: Early definitions of entrepreneurship centred on the willingness of entrepreneurs to engage in the calculated business-related risk (Brockhaus 1982). McClelland (1961, p.210) supported the postulation that 'practically all theorists agree that entrepreneurship involves, by definition, taking risks of some kind'. Risk taking appears to be one of the most distinctive features of entrepreneurial behaviour, since creating new ventures is by definition a risky business. Successful entrepreneurs would be willing to bear risk. But they must 'not only have the motivation to bear risk but must also be able to bear the same risk' (Say 1971).

This study found that these entrepreneurial engineers and accountants not only had the motivation to bear the risk but also were able to bear the same risk.

...I felt it is risky but I wanted to do it...That was the only thing. I was struggling with that decision during many nights. Anyhow I made the decision. It is my own decision. It is my own risk... (ESEV)

Further, it was found that they had borne the risk of transition from employment to entrepreneurship. EGML was well aware that he encountered a risk during the transition but it was a calculated risk and he analyzed it in every way before he moved in. 
An Empirical Study of Success Factors in Transforming Accounting and Engineering Professionals into Entrepreneurs in the Small and Medium Enterprise Sector, Sri Lanka

...That is a risk that every entrepreneur has to undertake I think... But I would say it was a well calculated risk. I calculated everything. I calculated the potential market that I have. The potentials of the things that I could do and... especially about the connections I have...human connections... In fact there was a risk. I can't say that there was no risk. But I think the calculated risk went well as I planned...

A significant finding of this study is that although all these entrepreneurial professionals tend to take a risk, it is a calculated risk and that calculated risk is minimized strategically. It is evident in the following responses of the interviewees.

... I had that risk...That is why I signed for the job. Six months after the signing the agreement while I was in the final semester things were successful. I was sure that I would earn from my own company as I earn from the job. So that risk became lower. That is why I rejected that job completely and went for that... (EDBL)

In contrast with the literature reviewed, there was a case study of one interviewee who identified that employment is riskier than self-employment. ATMD identified the risk of being an entrepreneur as follows:

... I felt it...But doing new things is less risky than working in a company because everything is under your control...

This response indicates that self-employment is more demanding and provides lower and riskier earnings than paid employment. These respondents did not directly state that they undertake the risk of transformation from employment to entrepreneurship without feeling it. They actually took calculated risks by minimizing them strategically. Based on that fact, it can be suggested that engineers and accountants become entrepreneurs by taking calculated risks, knowing that more benefits are there being an entrepreneur. Therefore risk taking can be considered a most important success factor in this transformation of engineers and accountants into entrepreneurs.

Need for achievement: There is a general consensus that 'need for achievement' (n-Ach) is a significant factor in entrepreneurial success. One of the most widely discussed traits of entrepreneurs is the n-Ach. McClelland's (1961) work was a pioneering effort to determine whether entrepreneurs display a certain psychological profile. 


\section{NSBM Journal of Management}

Vol. 1, No. 1, January - June, 2015

A number of interviewees stated what they want to achieve from their ventures as follows:

...but I want to be a global company...That is why I started with the name $\mathrm{X}$ International because I wanted to be in the international market from the beginning... I needed to have the sense of achievement. So I don't need even my own name coming out. I need the satisfaction of doing something... (EGML)

...I think I have achieved something. Rather if I worked...I mean as a businessman I have achieved lots of things. I cannot compare it with previous experience... (EBHL)

In all these instances it appears that need for achievement has a direct influence as a success factor for the engineers and accountants to become entrepreneurial engineers and accountants in the SME sector.

Internal locus of control: Locus of control refers to the perceived control over the events in one's life (Rotter 1966). People with internal locus of control believe that they are able to control what happens in their lives. On the other hand, people with external locus of control tend to believe that most of the events in their lives result from being lucky, being present at the right time, and the behaviours of powerful individuals. Brockhaus (1982) found that entrepreneurs have greater internal locus of control than the general population; therefore entrepreneurs believe that the outcome of a business venture will be influenced by their own efforts. Brockhaus (1982) further suggested that locus of control could distinguish entrepreneurs who are successful from those who are unsuccessful.

ATMD was very concerned about the control of his own life. In his words:

... when you work in a company how you worked, what you get, promotions are not under your control. All are under the control of someone else. However, if you start the business you put your effort... What you achieve is within your control. If you do well you would get the benefits out of it.... But if you are working in a company everything is the other way around. It is outside your control...

Professionals with high internal locus of control believe that they are able to exercise control over their environment and are unlikely to conform to external influences. Therefore, these entrepreneurs with high internal locus of control, relative to those low on this trait, will 
be more likely to try new approaches, pursue new opportunities, initiate change instead of reacting to events, and take risks. Therefore it is clear that internal locus of control is a success factor influencing engineers and accountants to become entrepreneurs.

Professional confidence: Professional confidence can be described as a dynamic, maturing personal belief held by a professional or student. This includes belief in the role, scope of practice, significance of the profession, and is based on their capacity to competently fulfill these expectations, fostered through a process of affirming experiences (Holland et al. 2012).

The data suggests that entrepreneurial engineers and accountants put thoughts and plan into their venture activities according to their inner feelings such as "I can do" through the professional background they are in. The decisions that they make as a consequence of this process seem to be robust and, although they may be aware of others disagreeing with their decision, they are still confident about their decisions. The following responses bring clear evidence of this:

...I was not concerned about what others said. What I was concerned was doing my own thing in the area which I know. You have a control of what you do ... you know your field and capacity is... (EBHL)

To analyze this further, it was found that the engineers were mainly capable of doing business in the area that they had specialized in. However, based on the sample that the researchers had interviewed, most of the entrepreneurial accountants are engaged in different types of commercial activities which they had never specialized in before. It was the knowledge of Accounting and Finance that gave them confidence in handling any types of business. This is demonstrated in the responses given by AUMH:

...Since I wanted to manage or develop this company, I had to learn everything. My financial knowledge really helped me to make the company a success. The engineer is normally the main man of the company's success. However he does not have a financial background. However I had all the areas known to me. I knew finance, marketing, management, HR etc. which helped me to manage this company very well. It is the real reason for its success...

The study argues that professional confidence is a success factor which facilitates the capacity of the professional individual to broaden and strengthen their likelihood of transforming as entrepreneurs rather than working in an organization. 


\section{NSBM Journal of Management}

Vol. 1, No. 1, January - June, 2015

Passion: Passion is deeply embedded in the folklore and practice of entrepreneurship. Dating back to Schumpeter's early writings (1951), researchers and practitioners alike have invoked passion to explain entrepreneurial behaviors that defy reason-based explanations, such as unconventional risk taking, uncommon intensity of focus, and unwavering belief in a dream. Entrepreneurial passion is defined as an intense positive feeling toward entrepreneurial tasks and activities that are relevant to the entrepreneur's self-identity (Cardon et al. 2009). Other scholars have conceptualized entrepreneurial passion as love of the entrepreneurial work (Baum \& Locke 2004). Passion implies strong feelings and high motivation. Most Entrepreneurs attribute their persistence, particularly in the beginning phase of starting a firm, to their great passion. Thus, entrepreneurial passion should be a driver and source of energy to work hard, long hours with high levels of effort and persistence (Baum \& Locke 2004, Cardon et al. 2009).

EGML and EDBL went on to explain how they interpret their passion:

... It is not like that I have been passionate not only in this field. In fact, I have interest ... passionate in many fields...I don't know why? In fact, I have interest in medicine as well. And perhaps I might do that. So it can happen. My interests are diverse...It is my passion... without that you can't succeed. You should be passionate in what you do. You have to have that... (EGML)

...We have to be passionate about what we are doing. Basically it is the thing that we love to do. If we are passionate about something we always try to do that and improve that...From my school days I had the passion to do computer science things... (EDBL)

Even if the entrepreneurs described passion differently, they tend to see it as arising from an intrinsic force such as feeling a love for what they do. They experience their passion physiologically or as feelings, which motivate action in response to these feelings, and contribute to the continuance of entrepreneurial actions. Thus, the presence of passion seems to be a key element in their capacity to sustain entrepreneurial action, particularly in the face of the challenges, difficulties and stresses of entrepreneurship. Thus, this study provides evidence that having a passion is a fundamental personal success factor which can be attributed to entrepreneurial engineers and accountants.

Need for recognition: Recognition can be described as an individual's intention to enjoy status, approval and recognition from one's family, friends and other people in the community 
An Empirical Study of Success Factors in Transforming Accounting and Engineering Professionals into Entrepreneurs in the Small and Medium Enterprise Sector, Sri Lanka

(Bonjean 1996, Nelson 1968). There is little literature on the concept of recognition and this study found that there are both empirical and theoretical gaps.

According to the responses of the interviewees, the need for recognition is far less important for these engineers and accountants personally. However, they expect to receive recognition in any other form from society directly or indirectly and it becomes a factor affecting engineers and accountants to become entrepreneurs.

When asked: Your transformation as an entrepreneur may be seen as a businessman by the society. Didn't you feel that you were going to lose the recognition given by society to the engineer?

There was a definite pattern in the responses. EBHL responded:

...No. The thing is we are different. We did an engineering degree. And I can't be a Machine Designer...In my business card my name appears as Director/ Mechanical Engineer. I do not say that I $m$ a director. I say I'm an Engineer. If I say I am a Director I will not get good recognition...

The following response was given by EGML:

...I don't think that engineers are that recognized or respected in Sri Lanka... Apart from their set circles....But in general (among?) the public the role of engineers is not well known compared to doctors. And I'm not concerned about the recognition. It is not really a factor. I don't want to be recognized personally. But I need to have the sense of achievement. So I don't need even my name to come out. I need the satisfaction of doing something...

However, the same EGML expressed his thoughts differently in another situation when he was asked where he wanted to be. His response was as follows:

... At the moment we serve only the Sri Lankan market. But I want to be a global company. That is why I started with the name X International. Because I wanted to be at the international level from the beginning... We are talking to overseas clients and we have a number of contacts overseas and we have been given recognition by them. So...hopefully in the future we will be able to be a global company... 


\section{NSBM Journal of Management}

Vol. 1, No. 1, January - June, 2015

Accordingly, EGML wants his company to be globally recognized.

A similar pattern reflected in the response given by ACCD.

... I want to go to the international level as my next step. X corporate should start the business under same brand at the international level. I want my firm to be also added to the existing branded audit firm chain in Sri Lanka...

From the evidence it became apparent that although entrepreneurial engineers and accountants do not expect the personal recognition, they want to have recognition for their venture and thereby achieve some kind of recognition. Therefore, it gives clear evidence that the need for recognition is a success factor affecting engineers and accountants to become entrepreneurs.

Independence: Independence can be described as an individual's desire for freedom, control, and flexibility in the use of one's time (Schein 1978, Smith \& Miner 1983). Independence is taking responsibility to use one's own judgments as opposed to blindly following the assertions of others (Shane 2003). Many researchers have observed that the entrepreneurial role necessitates independence: (1) the entrepreneur takes responsibility for pursuing an opportunity that did not exist before; (2) entrepreneurs are responsible for results, whether achieved or not achieved and, (3) individuals may pursue entrepreneurial careers because they desire independence. Hisrich (1985) found that one of the prime motivations for women starting business was a desire for independence.

APTC's explanation of her experience in her previous workplace clearly indicates how a similar need of the same person is seen from different standpoints because of the freedom of an individual. She further explained that there was no freedom in her previous work and she had to be in the office whether she had work or not. And it did not suit her and once she started her own business it has become the other way around.

A similar pattern emerged in the following response as well:

... If you are working in a company, you can't do what you want to do... Then free time is also a matter... I have much more free time even though I have to take care of my business more than if I work for a company. You don't have to wake up early in the morning and go to work... I like the freedom. Nobody is controlling you... (A focus group respondent who is a Chartered Accountant) 
An Empirical Study of Success Factors in Transforming Accounting and Engineering Professionals into Entrepreneurs in the Small and Medium Enterprise Sector, Sri Lanka

The interviewed entrepreneurs felt that they were far more independent as entrepreneurs than when they were employed under someone else. In corporations, the interviewees were restricted in how they choose to use their time. There is little room for freedom, control and flexibility in using one's time as the rules and procedures of corporations dictate what is or what is not permitted. As entrepreneurs they are free to use their time as they feel necessary. Independence was highly rated in most cases and they stated that they wanted their freedom in order to live according to their own lifestyles. This is another success factor that prompts them to become entrepreneurs.

Need to serve society: There is no literature found on the need for entrepreneurs to serve society. The need to serve society can be identified as an activity that improves the quality of life in society.

However, the findings of this study reveal a new concept that these professionals have a need to do something for society. The response given by ATMD indicates the pattern of this new concept.

... I think I want to contribute to Sri Lanka...other than that I have changed the lives of a few others as well...

The need to create jobs is clear evidence that entrepreneurial engineers and accountants have a need to give some social benefit to society and it has encouraged them to become entrepreneurs. Further, it is clear that there is a theoretical and empirical gap regarding the need for entrepreneurs to serve society.

Opportunity seeking: Opportunity identification involves not only technical skills like financial analysis and market research but also less tangible forms such as creativity, team building, problem solving, and leadership (Long \& McMullan 1984, Hills, Lumpkin, \& Singh 1997, Hindle 2004) while value can, of course, be created not only by starting new activities but also by improving the operation of existing activities. Research on opportunity identification tends to place greater emphasis on new activities. It was found that these professional entrepreneurs tend to always find opportunities in the market and the following responses bear evidence of that:

... There was an environment that I wanted to move away from my employment ...there was an environment for me to leave...I thought why I was existing and what I was doing. .. Why I am not going to take that chance... (ESEV) 
NSBM Journal of Management

Vol. 1, No. 1, January - June, 2015

These engineers and accountants always look for the opportunities available in the market and they do not hesitate to use their expertise to grab them. They are always on the lookout for opportunities and follow them. This shows that opportunity seeking is a success factor affecting engineers and accountants to become entrepreneurs.

\section{Influence of Environmental Factors in the Transformation of Employed Engineers and Accountants as Entrepreneurial Engineers and Accountants}

Family background: People who have a parent or close family member, who is self-employed are more likely to follow an entrepreneurial career (Matthews \& Moser 1996, Drennan et al. 2005). A family business background leads perhaps to lower barriers to entrepreneurial entry, since those having it may capitalize on their social ties and social capital (Greve \& Saleff 2003). Parents act as initial role models and the parents active in a family business influence future entrepreneurial intentions through changing attitudes and beliefs, as for example selfefficacy (Shapero \& Sokol 1982, Krueger et al. 2000).

As Basu and Virick (2008) stated, the experiences during early childhood and socialization at home and in school probably shape the attitudes of young people towards entrepreneurship. The literature is supported by the following statements given by the interviewees such as:

... From my childhood itself my father said...If I say it in his own words...

“mokekutawath yatath wela weda karanna epa" (i. e., 'Don't do anything under someone else') That was the main thing which came to my mind... (EBHL)

... My father always encouraged me...My father's first advice was that there is nothing impossible and that really struck with me a lot. I was a kid at that time. It hit me deeply... (ACCD)

According to the information gathered, family members provide assistance in the process, and sometimes help in finding the capital needed. The decision to become an entrepreneur or start a new business venture is complicated and multi-faceted, and previous studies by Kirkwood (2007) support the findings of this study. Parents, childhood experience and family businesses appear to be a strong influencing factor in the process.

According to some respondents, most of the undergraduates were from middle class or even lower than that and they depended on their parents and the government. Most of them were not trained to earn their own money. At the time these undergraduates passed out from 
university their parents were old. Therefore soon after graduation, they had to find a job to earn for the family. They not only had to take care of their parents, but also to take care of their brothers and sisters for their education that resulted in them being unable to take risks at that stage due to the commitment that they had towards their families. Hence family responsibilities prevent them from emerging as entrepreneurs although they want to be so. Apparently, this study indicates that family background is a most decisive success factor that matters when these professionals start thinking about their own ventures.

Social networks: No person has perfect information with which to make choices and decisions; individuals experience 'bounded rationality' because they are limited in their ability to process and store information (Simon 1976). In an earlier study, Hills, Lumpkin and Singh (1997) reported that entrepreneurs who used social network sources to learn of entrepreneurial opportunities (labeled 'network entrepreneurs') recognized significantly more opportunities than those who recognized the opportunities for their firms individually ('solo entrepreneurs'). They reported significant differences between solo and network entrepreneurs on a number of factors.

The evidence from this study revealed that these two professional groups have exploited their opportunities through their networks.

EGML responded as follows:

... Connections make all the differences. So networking is important....You have to approach them at the correct time....basically, the network essentially boosts your business... New connections were definitely a factor. If I didn't have a network obviously I wouldn't have started the business... because you can't just go to somebody and talk about your products or your business. You need to have prior connections...

A similar pattern emerged from the interview with ACCD:

... We can't put a paper advertisement. Printing leaflets... We can't put bill boards. Everything is about networks. I started at zero I did not have any one. I had only few friends ... That was very important because I did not have any clients. So first I spoke to them..."Guys, I want assignments from your companies"...They did it. Since they did it for me, I got clients...For my success networks helped me... 


\section{NSBM Journal of Management}

Vol. 1, No. 1, January - June, 2015

The important role played by contacts within an entrepreneur's social network to idea identification and subsequent opportunity recognition was empirically supported by the evidence from this research. Indeed, collaboration with industry on the one hand, and awareness and ability to exploit commercial opportunities on the other, are likely to be selfreinforcing. This is because the higher the level of interaction with industry, the more likely it is that these professionals will recognize the potential applications of their research and the better will be their understanding of market conditions and business processes. Thereby having a social network leads engineers and accountants to become entrepreneurs.

Perceived government policies: External factors play a role in the process of entrepreneurship. They could be a country's economy, competition, government regulations, etc. (Shane 2003). Environmental factors are important in deciding to act entrepreneurially; it is influenced by the legal system of the country, the industry and the maturity of it, available external capital, the state of the economy and so on (Shane 2003). The performance of the venture is influenced by government policies. One of the important aspects of government in entrepreneurship is to increase the business birth rate and survival rate of ventures with favorable policies for the small business (Mokry 1998).

In this study it was found that EDBL has a very positive perception of government policies:

.... I see a lot of encouragement from government for ICTA companies. To be honest, the success of our company really depends on the awards that we got....Up to now we got an mBillionth award, four Swaabhimani awards and one MBQSA. In our success story the awards are at the top. Because of them we have got a lot of recognition. If ICTA did not encourage us to apply for awards and if they did not organize such award ceremonies we wouldn't be recognized for our products or our talents...

EGML and ACCD are appreciative of the prevailing tax system mainly because local software development is free from income tax in Sri Lanka.

However, the perception of almost all interviewees is that government organizations are very ineffective:

... However the coordination of some government departments such as tax department is very inefficient ..."I do not think that there is a positive encouragement to support entrepreneurs by the government... (ACCD) 
An Empirical Study of Success Factors in Transforming Accounting and Engineering Professionals into Entrepreneurs in the Small and Medium Enterprise Sector, Sri Lanka

Further, the study reveals that the prevailing policies of the government are not a success factor in the performance of the entrepreneurs and favorable policies help countries to succeed. The majority of interviewees agreed that there is not enough support available from the government for entrepreneurs in Sri Lanka. This indicates that the perceived government policies affect engineers and accountants as an environmental factor, for them to become entrepreneurs.

Entrepreneurial culture: The document produced for the G20 Young Entrepreneur Summit by Ernst and Young (2011) describes the entrepreneurial culture as follows:

A strong entrepreneurial culture is the foundation of a dynamic economy. It reflects how a country's society supports the ideas and initiatives of entrepreneurs and how it can direct young people towards a career in business by enhancing their skills. A strong entrepreneurial culture means there is less of a stigma associated with failure and recognizes the crucial role of entrepreneurs in creating new jobs

This study found that the Sri Lankan culture does not support entrepreneurship and the existing culture is more towards employment. This was evident in all cases that were explored in interviews and the following responses can be extracted as examples:

... Whenever I go for a family gathering or wedding, all ask why you are baking, why you don't go for a job... you know that is how people think... (APTC)

...Then I continued my third year and fourth year in university. Then more pressure came from my parents, lecturers and society that I have to do a job even for one year. So I felt very down, because at one point I also decided that I would have to do both... (EDBL)

The prevailing non-entrepreneurial culture in the country was further highlighted by the response received from the focus group:

... There is big cultural problem in Sri Lanka. There is no proper respect for businessman. In Sri Lanka, a businessman is known as 'mudali'. I think that is a big issue. It is a big cultural problem. In society they don't give respect to a businessman compared to professionals... (A focus group respondent with an engineering background) 


\section{NSBM Journal of Management}

Vol. 1, No. 1, January - June, 2015

Listening to these respondents it was evident that the Sri Lankan culture is not a success factor in entrepreneurship. Sri Lanka's society is a risk averse society and thereby heavily pressure individuals to become job doers rather than entrepreneurs.

\section{Implications for Theory and Practice}

The traditional research stream on entrepreneurial behaviour has emphasized personal and environmental factors to explain why someone starts a new firm. The personal factors, or traits perspective, addresses several human attributes, such as risk taking (McClelland 1961), need for achievement (McClelland 1961) and internal locus of control (Rotter 1966). Similarly, it further emphasized that the environmental factors such as family background, social networks and perceived government policies also influence new starters. However, based on the findings discussed, it is clear that personal factors such as risk taking, need for achievement and internal locus of control as well as environmental factors such as family background, perceived government policies and social networks, influence engineers and accountants to become entrepreneurs in the SME sector. In addition, it was found that there are some other factors not proposed during the initial stage, namely, professional confidence (Holland et al. 2012), independence (Schein 1978, Smith \& Miner 1983), passion (Baum \& Lockey 2004), need to serve society, opportunity seeking (Long \& McMullan 1984, Hills Lumpkin \& Singh 1997, Hindle 2004) and entrepreneurial culture (Ernst \& Young 2011) which are specific impeding and impelling factors for employed engineers and accountants to become entrepreneurial engineers and accountants in the SME sector in Sri Lanka.

\section{Recommendations for Engineers and Accountants}

The findings highlight that engineers with a business background are able to exploit their opportunities more easily in their field of technology. Esbach (2009) concluded that together the combination of management and engineering provide an ideal underpinning for technological innovation and entrepreneurship. Therefore, it can be suggested that engineers who intend to become entrepreneurs should gain management knowledge too.

The findings emphasize that accountants are capable of doing many types of businesses even if they are not directly related to their profession. The supportive factor for that particular skill is the professional background that they have, covering a wide spectrum of business areas. Hence it is suggested that accountants should change their conventional way of feeling, thinking and acting to become more innovative and use their ability to search for new business opportunities. Being more practical enables them to use their professional background to become an entrepreneur in any business area. 
An Empirical Study of Success Factors in Transforming Accounting and Engineering Professionals into Entrepreneurs in the Small and Medium Enterprise Sector, Sri Lanka

The findings further revealed that both employed engineers and accountants, who have more family responsibilities and expect a high income soon after their graduation, should exploit business opportunities during the early stages of university life rather than in the final year. It helps them to develop their businesses from an early stage of their professional life. From these findings, it is concluded that having a proper income from the business at the end of one's university life enables these professionals to continue with their businesses rather than chasing after employers to get a job.

Moreover, it is suggested that for any engineer or any accountant the personal factors discussed in this study can be learnt or developed by them, and would be essential to emerge as entrepreneurs.

\section{Implications for National Level Policy Makers}

According to the findings it was revealed that perceived government support is not adequate for starters mainly due to inefficiency in government bodies. Therefore, the first implication would be that national policy makers should create a favorable environment for entrepreneurs by creating a supportive government environment for emerging entrepreneurs. Next, attention should be drawn to the prevailing tax system and it should be revised to provide a tax holiday for the first year as emerging entrepreneurs are really struggling to develop their business at the initial stage. According to the findings, maintaining documents to prove accounting details at the very first stage with the purpose of paying taxes is a real hassle for emerging entrepreneurs.

Secondly, the curricula of the education system should be revised to include entrepreneurship as a subject with the intention of producing more entrepreneurs among the professionals. The Sri Lankan education system aims to prepare students for government employment (Nanayakkara 1984). Engineering and Accounting undergraduates who are passionate to start their own venture should be recognized separately in universities. For example, engineers who have an interest in starting their own ventures should be given more business knowledge covering both theoretical and practical aspects. The focus of the education system should not be just to create engineers and accountants; rather it should be to foster entrepreneurial engineers and accountants who are passionate about what they do.

Thirdly, government should encourage the industry to give business opportunities for university students from the beginning of the second year of their university life. Thereby they get a chance to earn money and also get training on how to earn money. Hence the 


\section{NSBM Journal of Management}

Vol. 1, No. 1, January - June, 2015

responsibility of the government is to implement processes to improve the linkage between university and industry by being a mediator. Government should play a facilitative role and encourage more private sector participation providing skills development programmes (Kelegama 2002). Further, the industries and companies who run those kinds of programmes should be rewarded and recognized by the government.

Finally, although the economic context of Sri Lanka has changed in favour of entrepreneurship, the social cultural contexts need further changes to give impetus to entrepreneurship since the findings showed that the prevailing Sri Lankan culture is not entrepreneur- supportive (Ranasinghe 1996). Therefore, it is necessary to create a culture that shows more respect and recognition for entrepreneurs in the country. Thereby, the encouragement from society to become an entrepreneur would be higher than at present. Therefore, national economic policies should be prepared in a way that promotes more entrepreneurs from among engineering and accounting professionals in the country.

\section{Limitations}

Convenience sampling and snowball sampling may have resulted in the research being homogenous in nature. Therefore, the conclusions drawn from this data may not accurately represent the population. The interviewees were limited only to the Colombo District and the limited availability of the statistics relating to the research area should also be considered as a limitation.

\section{Directions for Future Research}

It was found that there are numerous stories of those entrepreneurs regarding their successful journeys and they strongly felt the need to share them with the researchers. It was also revealed that there are some secrets to success in their entrepreneurial lives.

Since the research focused only on engineers and accountants, the same research can be extended to other professionals such as marketers and academics to understand how they become or could become entrepreneurs. Since entrepreneurial ventures have been found to be instruments of change and growth of economies (Aloulou \& Fayolle 2005), it is worth studying other areas as well as it leads more educated entrepreneurs into the economy of a country.

Although women were included in the sample of entrepreneurs interviewed, this research was not able to make any generalizations as to gender as the number of women in the sample 
An Empirical Study of Success Factors in Transforming Accounting and Engineering Professionals into Entrepreneurs in the Small and Medium Enterprise Sector, Sri Lanka

was too small. However, during the interviews, it was understood that family commitments are an impeding factor for them to emerge as entrepreneurs. Therefore, it would be interesting to conduct further research, looking into the gender variable as it would be most relevant. Women are equally capable of making a substantial difference in entrepreneurial activities. Therefore, their tendency to become entrepreneurs should be investigated further.

The focus of this research was not on any particular religious group or specific race or nation. During the research it was found that Muslim or Islamic entrepreneurs have a special relationship with their religion where they follow certain principles as guided by the Koran. Therefore, it is worth extending the same research to different contexts, ethnic groups, etc.

The research focused on both engineers and accountants as one set of professionals and did not differentiate between these two groups in carrying out the research. However, it was revealed that entrepreneurial accountants are engaged in various types of business whereas entrepreneurial engineers are mainly engaged in technical fields. Therefore, differences of entrepreneurial behavior between these two groups should be further investigated.

\section{Conclusion}

Entrepreneurs can be developed through mental programming and a lifelong learning process. According to Nabi and Holden (2008, p. 547) and based on the cautious analysis suggested by the researcher personal factors what makes engineers and accountants successful entrepreneurs can be learnt or developed by themselves. Therefore, any engineer or any accountant can develop those factors to make him personally ready to exploit an opportunity as an entrepreneur. Further, having a proper entrepreneur- focused education system with a supportive culture enables more professionals to enter the entrepreneurial field. This research has reinforced the researchers' commitment to assist more employed engineers and accountants to become entrepreneurial engineers and accountants in small businesses in Sri Lanka.

\section{References}

Acs, Z \& Varga, A 2005, 'Entrepreneurship, agglomeration and technological change', Journal of Small Business Economics, vol. 24, no.3, pp.323-334.

Aldrich, H \& Cliff, J 2003, 'The pervasive effect of family on entrepreneurship: toward a family embeddedness perspective', Journal of Business Venturing, vol. 18, no.5, pp. 573- 596.

Aloulou, W \& Fayolle, A 2005,' A conceptual approach of entrepreneurial orientation within a small business context', Journal of Enterprising Culture, vol. 13, no.1, pp. 21-45. 


\section{NSBM Journal of Management}

Vol. 1, No. 1, January - June, 2015

Alwis, G, Perera, M \& Senethiraja, R 2010, 'The factors determining the entrepreneurial intention among IT professionals in Sri Lanka', viewed 15 February 2015, http://archive.cmb.ac.lk/research/ handle/70130/1626

Basu, A, \& Virick, M 2008, 'Assessing entrepreneurial intentions amongst students: A comparative study', viewed 17 February 2015, http://works.bepress.com/anuradha basu/12/

Barnes, J 1972, Social networks, Addison-Wesley, Philippines.

Baum, J \& Locke, E 2004, 'The relationship of entrepreneurial traits, skill, and motivation to subsequent venture growth', Journal of Applying Psychology, vol. 89, no. 4, pp.587-598.

Benzing, C, Chu, H \& Kara, O 2009, 'Entrepreneurs in Turkey: a factor analysis of motivations, success factors and problems', Journal of Small Business Management, vol. 47, no. 1, pp. 58-91.

Bonjean, C 1996, 'Mass, class and the industrial community: a comparative analysis of managers, businessmen, and workers', American Journal of Sociology, vol. 72, no. 2, pp.149-162.

Brockhaus, R 1982, The psychology of the entrepreneur-The Encyclopaedia of Entrepreneurship, Prentice Hall, Englewood Cliffs, NY.

Cardon, M , Wincent, J, Singh J \& Drnovsek, M 2009, 'The nature and experience of entrepreneurial passion', Journal of Academic Management Review, vol. 34, no. 3, pp. 511-532.

Chaston, I 1992, 'Supporting new small business start-ups', Journal of European Industrial Training, vol. 16 , no.10, pp.3-8.

Central Bank of Sri Lanka 1998, 'Economic progress of independent Sri Lanka', Central Bank of Sri Lanka, Colombo, pp.121-124.

Daft, R 1983, 'Learning the craft of organizational research', Academy of Management Review, vol. 8, no. 4 , pp. 539-546.

Drennan, J, Kennedy, J \& Renfrow, P 2005,'Impact of childhood experiences on the development of entrepreneurial intentions', International Journal of Entrepreneurship and Innovation, vol. 6, no. 4, pp. 231-238.

Esbach, J 2009, 'Relevance of engineering entrepreneurship, a Study at CPUT', Journal of Asia Entrepreneurship and Sustainability, vol. 3, pp. 108-123.

Ernst \& Young 2011, 'Entrepreneurs speak out', paper presented at the G20 Young Entrepreneur Summit, October 2011, viewed 04 March 2015, http://www.ey.com/Publication/vwLUAssets/ Entrepreneurs_speak_out_2012/\$FILE/Entrepreneurs\%20speak\%20out_2012.pdf

Gamage, A 2010, 'Small and medium development in Sri Lanka', viewed 15 February 2015, http:// www.smmeresearch.co.za/SMME\%20Research\%20General/Conference $\% 20$ Papers/SME\%20 development $\% 20$ in $\% 20$ Sri\%20Lanka.pdf

Gillham, B 2005, Research interviewing: the range of techniques, Open University, Maidenhead Press.

Gorman, G, Hanlon, D \& King, W 1997, 'Some research perspectives on entrepreneurship education, enterprise education and education for small business management: a ten-year literature review', International Small Business Journal, vol. 15, no. 3, pp. 56-79. 
An Empirical Study of Success Factors in Transforming Accounting and Engineering Professionals into Entrepreneurs in the Small and Medium Enterprise Sector, Sri Lanka

Greve, A \& Saleff, J 2003, Social networks and entrepreneurship-Entrepreneurship Theory and Practice, Free Press, New York.

Gunawardene, A 2011, 'The entrepreneurial behavior of Sri Lankan Accountants', MBA Research Paper (unpublished), University of Sri Jayewardenepura.

Guasch, J, Kuznetsov, Y \& Sanchez, S 2002, Small and medium sized enterprises in Argentina: a potential engine for economic growth and employment, World Bank Sector Rep. No. 22803-AR, World Bank, Washington DC.

Hansen, E 1995, 'Entrepreneurial networks and new organization growth', Entrepreneurship: Theory and Practice, vol. 19, no. 4, pp. 7-19.

Hisrich, R 1985, 'The woman entrepreneur in the United States and Puerto Rico: a comparative study', Leadership and Organizational Development Journal, vol. 5, pp. 3-8.

Hills, G, Lumpkin, G \& Singh, R 1997, 'Opportunity recognition: perceptions and behaviors of Entrepreneurs', Frontiers of Entrepreneurship Research, vol. 17, pp. 168-182.

Hindle, K 2004, 'Choosing qualitative methods for entrepreneurial cognition research: a canonical development approach', Entrepreneurship Theory and Practice, vol. 28, no. 6, p.575.

Holmgren, C \& From, J 2005, ' Taylorism of the mind: entrepreneurship education from a perspective of educational research', European Educational Research Journal, vol. 4, no. 4, pp. 382-390.

Johannisson, B 1990, 'Economics of overview_guiding the external growth of small firms', International Small Business Journal, vol. 9, pp. 32-44.

Kathlyn H, Middleton, L \& Uys, L 2012, 'Professional confidence: A concept analysis', Scandinavian Journal of Occupational Therapy, vol. 19, no. 2 , pp. 214-224.

Kelegama, S 2002, 'Indian Ocean regionalism: is there a future', Economic \& Political Weekly, vol. 37 , no. 25 .

Krueger, N, Reilly, M \& Carsrund, A 2000, 'Competing models of entrepreneurial intentions', Journal of Business Venturing, vol. 15, no.5, pp. 411-532.

Leedy, P \& Ormrod, J 2001, Practical research: Planning and design, 7th edn, Merrill Prentice Hall Upper Saddle River, NJ.

Liyanagama, R \& Wijewardene, K 2011, 'Factors affecting to migrate the professionals in Sri Lanka', MBA research paper (unpublished), University of Sri Jayewardenepura.

Long, W \& McMullan, W 1984, 'Entrepreneurship education in the nineties,' Journal of Business Venturing, vol. 2, no. 3, pp. 261-275.

Mallawa, R 2010, 'The entrepreneurial behavior of Sri Lankan Engineers', MBA research paper (unpublished), University of Sri Jayewardenepura.

Matthews, C \& Moser, S 1996, 'A longitudinal investigation of the impact of family background and gender on interest in small firm ownership', Journal of Small Business Management, vol.34, no. 2, pp. $29-43$.

McClelland, D 1961, The achieving society, Cambridge University Press. 


\section{NSBM Journal of Management}

Vol. 1, No. 1, January - June, 2015

Mead, D \& Liedholm, C 1998, 'The dynamics of micro and small enterprises in developing countries', Journal of World Development, vol.26, no.1, pp. 61-74.

Merriam, S 1998, Qualitative research and case study applications in education, Jossey-Bass, San Francisco.

Mokry, B 1998, Entrepreneurship and public policy: can government stimulate business start-ups?, Greenwood Press, Inc., Westport.

Muhammad, K, Abu, H, Jmal, A \& Adel, A 2011, 'Challenges faced by the Small and Medium Enterprises (SMES) in Malaysia: An intellectual capital perspective', International Journal of Current Research, vol. 6, no.33, pp.398-440.

Mulhern, A 1996, 'Venezuelan small businesses and the economic crisis: reflections from Europe', International Journal of Entrepreneurial Behavior \& Research, vol. 2 , no. 2, pp. 69-79.

Nabi, G \& Holden, R 2008, 'Graduate entrepreneurship: intentions, education and training', Journal of Education and Training, vol. 50, no. 7, pp. 545-551.

Nanayakkara, G 1984, 'Cultural imperatives of policy science', Vidyodaya, Silver Jubilee Issue, pp. 85-103.

Nelson, J 1968, 'Participation and integration: the case of the small businessman', American Sociological Review, no. 33, vol. 3, pp. 427-438.

Nohria, N 1992, Information and search in the creation of new business ventures: the case of the 128 venture group, Harvard Business School Press, Boston: MA.

Ponnamperuma, E 2000, SMEs in competitive markets, country paper, Asian Productivity Organization, Tokyo, pp. 295-313.

Pool, I \& Kochen, M 1978, Contacts and influence: social networks, Oxford University Press.

Ranasinghe, S 1996, 'Entrepreneurship education and training in Sri Lanka', Sri Lankan Journal of Management, vol. 1, no. 3, pp. 73-86.

Reynolds, P \& Lancaster, G 2006, 'A scheme to increase profitability in entrepreneurial SMEs', Journal of Small Business Entrepreneurship Development, vol. 13, no. 03, pp. 395-410.

Romer, P 1994, 'The origins of endogenous growth', Journal of Economic Perspectives, vol.8, pp. 3-22.

Rotter, J 1966, 'Generalized expectancies for internal versus external control reinforcements', Psychological Monographs, no.80, Whole No.609.

Say, J 1971, A Treatise on political economy, or the production, distribution and consumption of wealth, Augustus M. Kelley, New York.

Schumpeter, J 1934, The theory of economic development, Harvard University Press.

Schumpeter, J 1951, Imperialism and social classes, Kelley, New York.

Schmiemann, M 2008, Enterprises by size and class: overview of SMEs in the EU-Statistics in Focus, Eurostat, Luxembourg. 
An Empirical Study of Success Factors in Transforming Accounting and Engineering Professionals into Entrepreneurs in the Small and Medium Enterprise Sector, Sri Lanka

Schein, E 1978, Career dynamics: matching individual and organizational needs, Addison - Welsey Publishing, Reading, MA.

Shane, S 2003, A general theory of entrepreneurship: the individual-opportunity nexus, Edward Elgar: Cheltenham, U.K.

Shapero, A \& Sokol, L 1982, 'Social dimensions of entrepreneurship', in Kent, C., Sexton, D. and Vesper, K. (eds), The Encyclopedia of Entrepreneurship, pp.72-90, Prentice-Hall, Englewood Cliffs, NJ.

Simon, H 1976, Administrative behavior, 3rd edn, Free Press, New York.

Smith, N \& Miner, J 1983, Type of entrepreneur, type of firm, and managerial innovation: implications for organizational life cycle theory, Free Press, New York.

Strauss, A \& Corbin, J 1990, Basics of qualitative research: grounded theory procedures and techniques, Sage, Newbury Park, CA.

Swierczek, F \& Ha, T 2003, 'Entrepreneurial orientation, uncertainty avoidance and firm performance: an analysis of Thai and Vietnamese SMEs', International Journal of Entrepreneurship and Innovation, vol. 4, no.1, pp. 46-58.

Wickramasinghe, S 2011, 'The status of SME in Sri Lanka and promotion of their innovation output', Tech Monitor, pp. 11- 19. 